\section{Media Publikasi Promosi Kesehatan Indonesia The Indonesian Journal of Health Promotion}

\title{
Analisis Usia Menikah dan Status Pekerjaan yang Berhubungan dengan Tingkat Kecemasan Ibu Tentang Efek Samping DPT
}

\author{
Analysis Age of Marriage and Their Position In A Job That Deals With The Level of Anxiety \\ Mommy About Side Effects DPT
}

\author{
${ }^{(1)}$ Eddy Rahman , ${ }^{(2 *)}$ Yeni Riza \\ ${ }^{\left(1,2^{*}\right)}$ Fakultas Kesehatan Masyarakat Uniska Banjarmasin \\ (*)yeniriza86@gmail.com \\ (*) Corresponding Author
}

\begin{abstract}
Abstrak
Salah satu penyebab kematian bayi di negara berkembang termasuk Indonesia yaitu penyakit Difteri, Pertusis dan Tetanus (DPT). Imunisasi merupakan upaya pencegahan penyakit untuk menurunkan angka kesakitan, kecacatan dan kematian akibat penyakit yang dapat dicegah dengan imunisasi. Tujuan dari penelitian ini adalah untuk mengetahui analisis usia menikah dan status pekerjaan yang berhubungan dengan tingkat kecemasan ibu tentang efek samping DPT di wilayah Kerja Puskesmas Basirih Baru tahun 2018. Penelitian ini bersifat survei analitik pendekatan cross sectional. Populasi pada penelitian ini sebanyak 489 responden. Pengambilan sampel menggunakan rumus Slovin yaitu dengan teknik accidental sampling yaitu sebanyak 88 responden. Instrumen yang digunakan adalah kuesioner, menggunakan uji statistik chi square. Hasil penelitian menunjukkan bahwa sebagian besar responden mengalami cemas berat (58\%), menikah dibawah usia ideal $(47,7 \%)$ dan lebih banyak yang tidak bekerja (63,6\%). Terdapat hubungan antara usia menikah dengan tingkat kecemasan ( $\mathrm{p}$ value $=0,013$ ). Terdapat hubungan antara status pekerjaan dengan tingkat kecemasan $(\mathrm{p}$ value $=0,026)$. Disarankan kepada petugas puskesmas untuk meningkatkan program promosi kesehatan mengenai pentingnya imunisasi serta manfaat imunisasi untuk pencegahan terjadinya penyakit infeksi yang berbahaya bagi anak.
\end{abstract}

Kata Kunci : Tingkat Kecemasan; Efek Samping DPT

\begin{abstract}
One of the causes of infant mortality in developing countries including Indonesia is diphtheria, pertussis and tetanus. Immunization is prevention to reduce the number of morbidity, disabillity and mortlity due to diseases that can be prevented by immunization. The aim of the research is to know related factors with mother anxiety level about diptheria, pertussis, and tetanus (DPT) side effect in Basirih Baru Primary Health Care in 2018. The research use analitical survey with cross sectional approach. The population in this research 489 respondents. Sampling use Slovin formula with accidental sampling technique are 88 respondents. Instrument is questionnaire and use Chi Square test. The results showed that most respondents experienced severe anxiety (58\%), married under ideal age (47,7\%) and more who did not work (63.6\%). There is a relationship between the age of marriage and the level of anxiety ( $p$ value $=0.013)$. There is a relationship between employment status and anxiety level $(p$ value $=$ 0.026). Suggestion to primary health care worker is to increase health promotion program about importance and benefit of immunization to prevent dangerous infection for infants.
\end{abstract}

Keywords: anxiety level; diphteria pertussis and tetanus side effects 


\section{PENDAHULUAN}

Salah satu upaya pencegahan penyakit adalah dengan dilakukannya imunisasi. Imunisasi merupakan cara untuk meningkatkan kekebalan tubuh seseorang terhadap suatu penyakit, sehingga kelak jika terpapar penyakit tidak akan menderitas penyakit tersebut. Imunisasi merupakan program upaya pencegahan Kementrian Kesehatan Republik Indonesia untuk menurunkan angka kesakitan, kecacatan, dan kematian akibat penyakit yang dapat dicegah dengan imunisasi (PD31), yaitu Tuberkulosis, Difteri, Pertusis, Hepatitis B, Polio, dan Campak. Imunisasi juga merupakan upaya nyata pemerintah untuk mencapai Millenium Development Goals (MDGs), khususnya untuk menurunkan angka kematian anak. Indikator keberhasilan pelaksanaan imunisasi diukur dengan pencapaian Universal Child Immunization (UCI) yaitu minimal $80 \%$ bayi di desa atau kelurahan telah mendapatkan imunisasi lengkap, yang terdiri dari BCG, Hepatitis B, DPT-HB, Polio dan Campak (1).

Visi pembangunan kesehatan untuk mencapai tujuan Indonesia Sehat 2016 adalah masyarakat, bangsa dan negara yang ditandai oleh penduduknya hidup dalam lingkungan dan dengan perilaku hidup sehat, memiliki kemampuan untuk menjangkau pelayanan kesehatan yang bermutu secara adil dan merata, serta memiliki derajat kesehatan yang setinggi-tingginya di seluruh wilayah Republik Indonesia (2).

Imunisasi DPT adalah suatu vaksin 3-in-1 yang melindungi terhadap Difteri, Pertusis dan Tetanus. Difteri adalah suatu infeksi bakteri yang menyerang tenggorokan dan dapat menyebabkan komplikasi yang serius dan fatal. Petusis atau batuk rejan atau batuk 100 hari adalah penyakit pada saluran pernafasan yang disebabkan oleh boerdetella pertusis. Tetanus adalah infeksi bakteri yang bisa menyebabkan kekakuan pada rahang serta kejang. Vaksin DPT adalah vaksin 3-in-1 yang bisa diberikan kepada anak yang berumur kurang dari 7 tahun. Biasanya vaksin DPT terdapat dalam bentukan suntikan, yang disuntikan pada otot lengan atau paha. Imunisasi DPT diberikan sebanyak 3 kali, yaitu pada saat anak berumur 2 bulan (DPT I), 3 bulan (DPT II) dan 4 bulan (DPT III), selang waktu tidak kurang dari 4 minggu. Imunisasi DPT ulang diberikan 1 tahun setelah DPT III dan pada usia prasekolah (2).

Berdasarkan perolehan data dari Dinas Kesehatan Kota Banjarmasin target pencapaian imunisasi DPT tahun 2017 belum tercapai yaitu DPT-HB1 96,8\%, DPT-HB2 94,6\%, DPT-HB3 94,3\%, dimana seharusnya target pencapaian imunisasi DPT-HB mencapai target 100\%. Dari data Puskesmas Basirih Baru Tahun 2017 jumlah bayi di imunisasi DPT-HB1 ada 385 bayi (79,5\%), DPT-HB2 ada 370 bayi (76,4\%), DPT-HB3 ada 364 bayi (75,2\%) dari target 489 orang. Angka cakupan di Puskesmas Basirih Baru tersebut tentunya masih sangat rendah jika dibandingkan dengan jumlah sasaran atau target, serta standar dari Kemenkes yang menargetkan seluruh desa/ kelurahan mencapai $100 \%$ UCI.

Tujuan penelitian untuk mengetahui analisis usia menikah dan status pekerjaan yang berhubungan dengan tingkat kecemasan ibu tentang efek samping DPT di wilayah kerja Puskesmas Basirih Baru Kota Banjarmasin.

\section{METODE}

Penelitian yang digunakan adalah survei analitik dengan pendekatan cross sectional. Populasi pada penelitian ini adalah semua ibu yang memiliki bayi $>2$ bulan -9 bulan sudah diberikan imunisasi DPT. Dengan jumlah sampel 88 responden dengan kriteria memiliki bayi $>2$ bulan -9 bulan. Data primer diperoleh langsung melalui kuesioner yang dibagikan kepada responden. Untuk mengetahui hubungan analisis yang dilakukan terhadap variabel yang diduga berhubungan. Analisis data dengan uji statistik chi square dengan menggunakan aplikasi SPSS.

\section{HASIL}

Tabel 1 (lampiran) menggambarkan karakteristik subjek penelitian, bahwa dari 88 responden yang memiliki 
tingkat kecemasan ringan sebanyak 37 responden (42\%) dan yang memiliki tingkat kecemasan berat 51 responden (58\%). Hasil penelitian dari usia menikah, didapatkan 42 responden $(47,7 \%)$ yang menikah dibawah usia ideal $(<18$ Tahun). Terdapat 46 responden (52,3\%) yang menikah usia ideal ( $>19$ Tahun). Hasil penelitian pada status pekerjaan menunjukkan bahwa ada 56 responden $(63,6 \%)$ yang tidak bekerja dan 32 responden $(36,4 \%)$ yang bekerja.

Tabel 2 (lampiran) menunjukkan data bahwa 42 responden yang menikah di bawah usia ideal lebih banyak mengalami cemas berat sebanyak 30 responden (71,4\%), sedangkan dari 46 responden yang menikah usia ideal paling banyak mengalami cemas ringan sebanyak 25 responden (54,3\%). Dari hasil uji statistik didapatkan p value $=$ 0,013 dengan $\mathrm{p}<\alpha 0,05$, maka $\mathrm{H}_{0}$ ditolak yang artinya terdapat hubungan antara usia menikah dengan tingkat kecemasan di wilayah kerja Puskesmas Basirih Baru.

Tabel 3 (lampiran) menunjukkan data bahwa 32 responden yang bekerja paling banyak mengalami cemas berat sebanyak 24 responden (75\%), sedangkan dari 56 responden yang tidak bekerja lebih banyak mengalami cemas ringan sebanyak 29 responden $(51,8 \%)$, dari. Dari hasil uji statistik didapatkan $\mathrm{p}$ value $=0,026$ dengan $\mathrm{p}<\alpha 0,05$, maka $\mathrm{H}_{0}$ ditolak yang artinya terdapat hubungan antara status pekerjaan dengan tingkat kecemasan di wilayah kerja Puskesmas Basirih Baru.

\section{PEMBAHASAN}

Pada dasarnya, kecemasan merupakan hal wajar yang pernah dialami oleh setiap manusia. Kecemasan sudah dianggap sebagai bagian dari kehidupan sehari-hari. Kecemasan adalah suatu perasaan yang sifatnya umum, dimana seseorang merasa ketakutan atau kehilangan kepercayaan diri yang tidak jelas asal maupun wujudnya (6).

Hasil penelitian ini terdapat 30 responden yang menikah dibawah usia ideal yang mengalami cemas berat. Dapat disimpulkan bahwa ibu yang masih berusia muda akan lebih cemas dibandingkan dengan ibu yang berumur tua. Hal ini karena ibu yang tergolong dalam usia muda masih belum siap dalam hal psikologis. Untuk ibu yang tergolong umur matang dan tua sudah akan lebih mudah dalam mengontrol tingkat kecemasan tersebut.

Hal ini sejalan dengan Long dalam Rahayu (2010) bahwa seseorang yang berumur muda akan lebih cemas dari yang berumur lebih tua. Umur dipandang sebagai suatu keadaan yang menjadi dasar kematangan dan perkembangan seseorang, semakin tua umur seseorang semakin konstruktif dalam menggunakan koping terhadap masalah yang dihadapi dan semakin muda umur seseorang akan semakin sulit beradaptasi dalam menghadapi masalah maka akan sangat mempengaruhi kodisi psikologisnya, sehingga seseorang yang berumur muda akan lebih cemas dari pada yang berumur lebih tua (5).

Penelitian Muhlisin dan Pratiwi, 2017 yang mengatakan bahwa seseorang yang bekerja dapat mengembangkan pemikirannya, namun disisi lain pekerjaan juga dapat menganggu peran lain yang dimiliki individu hal ini dapat membuat terjadinya ketidakefektifan koping seperti terjadinya kecemasan. Kecendrungan ibu-ibu yang berstatus tidak bekerja dengan tingkat cemas rendah juga dipengaruhi oleh faktor waktu. Dimana ibu yang tidak bekerja memiliki waktu yang lebih banyak disbanding dengan ibu yang memiliki status pekerjaan, sehingga hal tersebut berpengaruh terhadap tingkat kecemasan ibu dalam memberikan imunisasi DPT pada bayi 2-9 bulan (4).

Penelitian Muamalah (2006) menyatakan bahwa ada hubungan yang signifikan antara pekerjaan ibu dengan imunisasi DPT dan Campak. Imunisasi hepatitis DPT dan Campak adalah salah satu imunisasi dasar pada bayi sehingga hasil penelitian tersebut sejalan dengan hasil penelitian yang sudah dilakukan, jadi pekerjaan termasuk faktor yang mempengaruhi status imunisasi dasar bayi (3). 


\section{KESIMPULAN DAN SARAN}

Sebagian besar ibu di wilayah kerja Puskesmas Basirih Baru mengalami tingkat kecemasan berat sebanyak 51 responden $(58,0 \%)$. Ada hubungan antara usia menikah dan status pekerjaan dengan tingkat kecemasan ibu tentang efek samping DPT di Wilayah Kerja Puskesmas Basirih Baru.

Perlunya peningkatan peran serta program promosi kesehatan untuk meningkatkan pengetahuan pada masyarakat terutama ibu yaitu tentang imunisasi DPT. Hal ini dapat dilakukan dengan cara memberikan penyuluhan kesehatan kepada ibu dan masyarakat umum oleh kader kesehatan untuk memberikan edukasi kepada masyarakat mengenai pentingnya imunisasi serta manfaat imunisasi untuk pencegahan terjadinya penyakit infeksi yang berbahaya bagi anak.

\section{DAFTAR PUSTAKA}

1. Depkes RI, 2010. Kementrian Targetkan Tahun 2014 Seluruh Desa/Kelurahan 100\% UCI. http://depkes.go.id [diakses pada 15 April 2018]

2. Dinkes, 2015. Visi dan Misi Indonesia Sehat 2015. Banjarmasin. Dinas Kesehatan Provinsi Kalimantan Selatan.

3. Muamalah, Siti. 2006. Faktor-faktor Yang Berhubungan dengan Status Imunisasi Difteri Pertusis Tetanus (DPT) dan Campak. Skripsi. Jurusan Ilmu Kesehatan Masyarakat UNNES Semarang

4. Muhlisin, A., \& Pratiwi, A. (2017). Community-based participatory research to improve primary mental health services. International Journal of Research in Medical Sciences, 5(6), 2524-2528. http://msjonline.org/index.php/ ijrms/article/view/3176)

5. Rahayu, E. 2010. Koping Ibu Terhadap Bayi BBLR.Fakultas Kedokteran Universitas Dipanegoro. Semarang.

6. Sutardjo Wiramihardja. (2005). Pengantar Psikologi Abnormal.Bandung: Refika Aditama. 


\section{LAMPIRAN}

Tabel 1. Distribusi Frekuensi Variabel Penelitian

\begin{tabular}{ccc}
\hline Variabel & n & \% \\
\hline Usia Menikah & 42 & 47,7 \\
Menikah dibawah usia ideal & 46 & 52,3 \\
Menikah usia ideal & & \\
Status Pekerjaan & 32 & 36,4 \\
Bekerja & 56 & 63,6 \\
Tidak Bekerja & & 58,0 \\
Tingkat Kecemasan & 51 & 42,0 \\
Cemas Berat & 37 & $\mathbf{1 0 0}$ \\
Cemas Ringan & $\mathbf{8 8}$ & \\
Total & &
\end{tabular}

Tabel 2. Hubungan Usia Menikah dengan Tingkat Kecemasan

\begin{tabular}{|c|c|c|c|c|c|c|c|}
\hline \multirow{3}{*}{ Usia Menikah } & \multicolumn{4}{|c|}{ Tingkat Kecemasan } & \multirow{2}{*}{\multicolumn{2}{|c|}{ Total }} & \multirow{3}{*}{$\mathrm{p}$ value } \\
\hline & \multicolumn{2}{|c|}{ Cemas Berat } & \multicolumn{2}{|c|}{ Cemas Ringan } & & & \\
\hline & $\mathrm{n}$ & $\%$ & $\mathrm{n}$ & $\%$ & $\mathrm{n}$ & $\%$ & \\
\hline Menikah dibawah usia Ideal & 30 & 71,4 & 12 & 28,6 & 42 & 100 & \multirow{3}{*}{0,013} \\
\hline Menikah Usia Ideal & 21 & 45,7 & 25 & 54,3 & 46 & 100 & \\
\hline Jumlah & 51 & 58,0 & 37 & 42,0 & 88 & 100 & \\
\hline
\end{tabular}

Tabel 3. Hubungan Status Pekerjaan dengan Tingkat Kecemasan

\begin{tabular}{|c|c|c|c|c|c|c|c|}
\hline \multirow[t]{3}{*}{ Status Pekerjaan } & \multicolumn{4}{|c|}{ Tingkat Kecemasan } & \multirow{2}{*}{\multicolumn{2}{|c|}{ Total }} & \multirow{3}{*}{$\mathrm{p}$ value } \\
\hline & \multicolumn{2}{|c|}{ Cemas Berat } & \multicolumn{2}{|c|}{ Cemas Ringan } & & & \\
\hline & $\mathrm{n}$ & $\%$ & $\mathrm{n}$ & $\%$ & $\mathrm{~N}$ & $\%$ & \\
\hline Bekerja & 24 & 75,0 & 8 & 25,0 & 32 & 100 & \\
\hline Tidak Bekerja & 27 & 48,2 & 29 & 51,8 & 56 & 100 & 0,026 \\
\hline Jumlah & 51 & 58,0 & 37 & 42,0 & 88 & 100 & \\
\hline
\end{tabular}

